\title{
Fiscal Tribal Dilemma: Imbalance in Protectionism and Optimum Resources Utilization Policies in North Eastern States of India
}

\author{
Samir Ul Hassan ${ }^{1 *}$ and Biswambhara Mishra ${ }^{2}$ \\ ${ }^{1}$ Department of Economics, University of Science \& Technology, Meghalaya, India \\ ${ }^{2}$ Department of Economics, North Eastern Hill University, Shillong, Meghalaya, India \\ *Corresponding author: samirul.hassan@yahoo.com
}

\begin{abstract}
The paper is an attempt to assess the fiscal performance of eight north eastern states of India over a period of sixteen years $(2000$ - 2016). The paper constructs a composite index to measure the level of fiscal performance across the states based on their indices where each index is constructed based upon three fiscal related variables. Based on the composite fiscal performance index the study observes that the fiscal performance of most of the NE states is inconsistent and deteriorating over the years due to increasing deficit burden, poor own revenue capacity and high expenditure-debt serving ratio. The peculiar situation in the North Eastern states and the inherent restrictions implies that these states are faced with hurdles in the implementation of policies. NE states are favored states, getting large tax preferences, exempted from paying direct taxes; enjoy a number of subsidies, have rigid/ undefined property rights regime, which hinders the identification of the potential of the economy. We believe that it is not protectionist policies rather it is the failure to harmonize protectionism with policies geared towards efficient resources management policies that undermines the fiscal health of the states, resulting in depressed developmental outcomes. Therefore, the institutional arrangement which vitiates fiscal health of the North Eastern states and adversely affects economic development is the outcome of the incongruity between protectionism and policies aimed at resources utilization. JEl Classification: H21, H62, H68, H83, P35
\end{abstract}

Keywords: Fiscal performance, protectionism, resources utilization, Political stability,

The North-Eastern region of India is a region typically characterized by a greater dependence on agriculture. Around 90 percent of its population depends on agriculture as a main source of livelihood. The region is also unique in the sense that a majority of the people residing here are mainly the tribal population. Significant development has been witnessed in different spheres in these economies, since independence. Yet access to opportunities for a 'reasonable minimum' standard of living in the region is comparatively lower to that of other states of the country. The fiscal health of the different states in the region is by no means encouraging at all, where the states' own tax revenue contributes hardly 17 percent of the total tax receipts of the states. In these states where their own tax revenue contributes no more than 10 percent the states' income, the aggregate government expenditure constitutes as high as 115 percent.

Over a period of time the North-Eastern states have developed a dependency syndrome as is evident from an explosive cycle of public expenditure growth in most of the states. Coupled with this, there is an increasing demand for grants-in-aids and other Central assistance to help bridge the gap of large budgetary deficits. This reflects an inadequacy on their part to generate enough resources to meet the changing volatile fiscal situation. A number of factors could be attributed to such a state of affairs: (i)low level of economic activities coupled 
with a low level of economic base, (ii) unregulated parallel economy not only due to flourishing trade of imported goods and commodities from the neighboring countries but also due to the various fringe tax benefits of direct taxation particularly of Income tax and lastly (iii) Social unrest and political instability that these economies experience from time to time.

As a whole, the repercussion from all these forces at work has resulted in various leakages not only in tax generating capacity but also in narrowing down the tax base of various taxes in the region. If we are to assign a cause-effect relationship to this type of vexed problem then we can argue that the failures on the part of the state governments in this region to mobilize adequate financial resources in order to carry out their various developmental plan programs, has been mainly responsible for their low level of economic activities, low level of economic base and their final culmination in the form of social unrest. If we assign a terminology to this poor state of affairs in the fiscal front, we may term it as a tribal fiscal dilemma.

Further, efficient fiscal systems entail proper utilization of funds, revenue mobilization, political stability and good governance which are found missing in the fiscal arrangement in the region. The peculiar situation in the North Eastern states and the inherent restrictions implies that these states are faced with hurdles in the implementation of policies. NE states are favored states, getting large tax preferences, exempted from paying direct taxes; enjoy a number of subsidies, have rigid/ undefined property rights regime, which hinders the identification of the potential of the economy. We believe that it is not protectionist policies rather it is the failure to harmonize protectionism with policies geared towards efficient resources management that undermines the fiscal health of the states, resulting in depressed developmental outcomes. Therefore, the institutional arrangement which vitiates fiscal health of the North Eastern states and adversely affects economic development is the outcome of the incongruity between protectionism and policies aimed at resources utilization and we also term it as Tribal Fiscal-dilemma.

The intricate relationship between the set of variables implicitly describes the existence of fiscal tribal dilemma. A plausible exposition/model based on these arguments can therefore be developed.

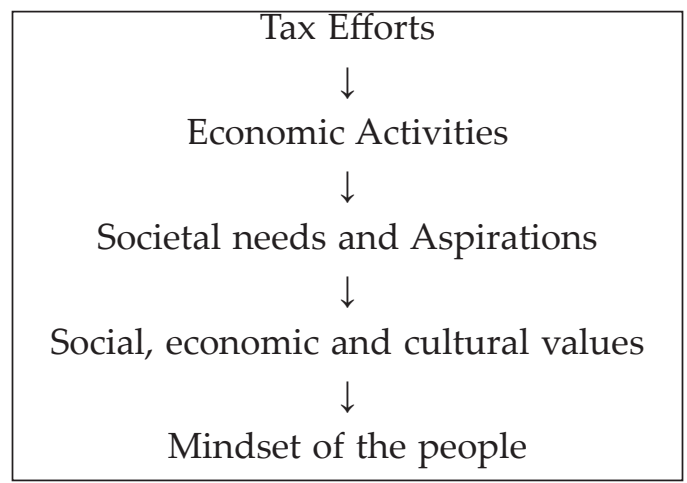

The mind set is invariably linked to a society's fabric and is a witness to its process of social and economic change. The dynamism in the mindset is hence associated with the contemporary changes in the economy and society, both on the external and internal fronts. In the external front what warrant such change are institutional in nature. Changes in the internal front require inherent changes within the individual themselves-to make the individuals more responsive to societal needs and aspirations. More precisely, the need is a paradigm shift from the perceived social value to the real social value. This would have an impact in effecting a change in how a given society goes about organizing and understanding reality.

The question therefore that requires attention is, whether our schizophrenic approach and attitude to economic development which has resulted in a narrow economic base?. To this extent the paper will work on two fronts; first the paper evaluate the fiscal performance of North Eastern states based on one composite index related to deficit management, revenue mobilization, expenditure management and debt servicing. Secondly, the paper will identify the variables related to tribal society ranged from economic, political, social etc and analyze their magnitude of relationship with fiscal health of the state to prove our argument that the poor fiscal and economic development in this region is due to incongruity between protectionism and policies aimed at resources utilization which we call FiscalTribal dilemma.

\section{REVIEW OF LITERATURE}

The determinants of Fiscal imbalance/performance have received wide attention at international and 
national level. Notable studies which observes fiscal performance in terms of public debtin India are Lahiri and Kananan, (2000); Acharya, (2001); Buter and Patel, (1992); Patnaik, (1996) and Ahluwalia, (2002). These studies argued that apart from economic instability; the slow performance of revenue generation, improper utilization of funds, political stability and governance are the factors which reflect the quantum of fiscal imbalance in Indian states. Similarly, the notable studies carried out to study the fiscal performance based on state government debt are Elena and Nagarajan, (2007); Rajaraman et al. (2005) and Dholakia et al. (2004). Hassan et al. (2016a, 2016b) argued that the last one decade the increasing public expenditure on infrastructure such as roads, railways, or communication systems and the provision of basic education and medical services raises the economic potential of economy on one hand and increase the social standard of the people on other hand . Further, Hassan and Mishra (2017) measure determinants of government expenditure by linking government expenditure to socioeconomic institutions such as income level, education, and healthcare that are assumed to be targeted by public spending. In terms of Nuxes between economic policies and development Hassan and Mishra (2017) study the nexus between government expenditure and Economic growth in Jammu and Kashmir. The study shows the non existence of a casual relationship running from government expenditure to economic growth. The study argued that aggregate government expenditure and its various components has no long-term relation with economic growth while in short run government expenditure and its components have very week adjustment power towards long run equilibrium in economic growth.

In terms of NE states, it is argued that since these states are special category states and their developmental expenditure is mostly financed with the help of special assistance from the centre and the private investment is negligible, the public expenditure plays a crucial role in the growth of Gross State Domestic Product (GSDP) Sarma and Nayak, (2006). In a situation where the primary expenditure is compacted, automatically the victim is the developmental capital outlay, which ultimately results in reduction in growth (Nayak and Rath, 2010). Further, reliant liabilities, primarily in the form of issuance of guarantees by the state governments, remain another area of concern. The strong presence of reliant liabilities calls for a holistic assessment of debt position of states by estimating their off-budget fiscal position including the impact of operations of state public sector enterprises (Kaur et al. 2014). To observe fiscal performance after fiscal reform programs (Dash, 2011) measured the fiscal performance of Tripura by evaluating its performance over the time period 1990- 91 to 200910 and concluded that the state should maintain its fiscal discipline in terms of deficit management and own revenue augmentation to have sustainable long term financial stability.

Similarly, Dash and Tiwari, (2011) ranked NE states according to their fiscal performance and conducted the nonlinear stationary test used by Ucar and Omay (2009). They observed that Arunachal Pradesh ranks at bottom and fiscal performance of northern sates of India is liner non-stationary. Dash, (2015) studied growth performance and debt position of NE states and concluded that growth performance is not satisfactory rather suffering from huge mounting public debt. Mishra et al. (2005) studied the growth and determinants of public expenditure in north-eastern states in general and Nagaland in particular for thirty-eight years, i.e., from 1963-64 to 2000-01. The study takes into account public expenditure as a dependent variable whereas a combination of both economic variables and political variables like manufacturing sector, service sector, the sectoral incomes originating in agricultural sector and the remaining sectors are taken as the independent variables. The result of the study suggests that both Congress and non-congress regimes have negative impact on the growth of nondevelopmental expenditure in the state. The study further concludes that ideological leanings of the parties in power or a change of government from non congress to congress does not seem to make any systematic difference to the determination of public expenditure in the state of Nagaland.

Another study conducted by Mishra (2006), concluded that the tax generating capacity of the north-eastern states does not cope up with its increased public expenditure programmes. The study revealed that the revenue expenditure and capital expenditure on an average constituted more 
than 70 percent and less than 30 percent of total expenditure respectively. This exhibited the pattern and direction of public expenditure whereby the states has not been able to pursue expenditure policies in consonance with the long term goals of achieving a desirable rate of economic progress. Suresh and Mishra (2010) in their work 'Public Expenditure and Human Development in NorthEast India- a case study of Meghalaya', stated that a lopsided approach that has been followed by the state government in terms of investment decisions, of giving lesser importance to the development of physical capital, has not only slowed down the indicators of human development but also resulted in a slow pace of economic growth of the state. Their study reveals that at the regional level, there is a positive functional relationship between public expenditure on social sectors and human development and that public expenditure on social services had a stronger impact on human development than economic growth.

\section{Background of the study}

India's North Eastern states are clubbed under the category of special status states. These states; such as (Arunachal Pradesh, Assam, Manipur, Meghalaya, Mizoram, Nagaland, Sikkim and Tripura) are characterized by geographical problems and other socio-economic and political issues for which these states are declared as the special category states and awarded with special assistance from the central government. India's North Eastern states are clubbed under the category of special status states. These states; such as (Arunachal Pradesh, Assam, Manipur, Meghalaya, Mizoram, Nagaland, Sikkim and Tripura) are characterized by geographical problems and other socio-economic and political issues for which these states are declared as the special category states and awarded with special assistance from the central government.

The North Eastern States also known as land of seven sisters are very magnificently gifted. The North Eastern region covers 5.5 per cent of the total geographical area of the country and accounts for 3.9 per cent of the national population and 2.7 per cent of all-India net domestic product (NDP). The richness of landscape, geographical, ecological diversity and range of communities residing in these states has made NE states one of the most ethnically and linguistically diverse regions in Asia. Each state in the region has its own distinct culture and tradition.

Despite rich endowments, the NE region represents one of the low developed regions of the country on number of development indicators. Due to the peculiar geographical, economic and socio-cultural features, the economy of this region has a unique character. A well-functioning financial system is the key to sustainable economic development for this region. Given the special difficulties faced by the North-Eastern region, special initiatives needs to be taken to eradicate the constraints which often come in managing the fiscal system of this region. The last decade was characterized by high economic growth at the all-India level but such high level growth was hardly seen in NE regional states. Over the ten year period, 2006-16, the weighted average NSDP growth in NES was lower at 5.2 per cent as compared with 7.1 per cent at the all-India level. There were, however, significant inter-state variations within NES with the growth performances of three states, viz., Nagaland, Arunachal Pradesh and Tripura being better than the all-India average. The low growth in Assam and Manipur was mainly due to the poor performance of agriculture and industry. While the growth rate in agriculture has been particularly low in Assam and Mizoram, the growth rate of agriculture in Nagaland was high. An important lesson from this is that if the states replicate the best sectoral growth pattern within the region, growth in NES could easily surpass the all-India level.

Sectoral analysis reveals that the economic structure of the NES more or less mirrors that of the Indian economy as a whole with the services sector dominating the economic activity. However, the share of industry in GDP was half of that of the Indian economy as a whole. The need, therefore, is to place a greater emphasis on promoting the growth of the industrial sector in the region. Notwithstanding significant differences in growth rates, the growth in per capita real income during the period 2000-01 to 2007-08 in NES was almost twice as the all-India level, with significant interstate differences.

Keeping in consideration the state of fiscal system in NE states, the primary aim of this work here is to examine all of the pieces of the fiscal decision- 
making environment together and therefore the main objectives of this paper is to (i) To analyze the efficiency of fiscal system of NE states by different deficit indicators. (ii) To examine the significant factors which keep the level of fiscal performance low in NE states.

\section{Sources of Data}

The study is based primarily on the secondary sources of data. The major sources of data for the study will be the annual budget papers of the NE states including memorandum submitted to various Finance Commissions for the period under study. We also use the budgetary data wherever possible relating to India as published from time to time in the Reserve Bank of India Bulletin and CAG reports. Further, certain relevant data was collected from election commission of India, ministry of Home affairs and south Asian Terrorism portal.

\section{METHODOLOGY}

The first primary objective of the study is to measure the fiscal performance and determinants of such fiscal performance in North eastern states of India during the period 2006-07 to 2015-16. The fiscal performance can be analyzed in terms of revenue generating capacity, deficit management and maintains of expenditure and servicing. To this extent the fiscal performance has been analyzed by a composite fiscal performance index for NE known as North East Fiscal performance Index (NEFPI) following the approach of Dash (2011).

NEFPI is consisting of three individual indices such as (A) Deficit Indicator Index (DII), (B) Own Revenue Effort Index (OREI) and (C) Expenditure and Debt Servicing Index (EDSI). Each indicator indices are consisting of ratios of fiscal indicators. (A) Deficit Indicator Index (DII) is consist of (i) Gross Fiscal Deficit as a proportion of Total Expenditure (GFD/TEX), (ii) Revenue Deficit as a proportion of Net Fiscal Deficit (RD/NFD) and (iii) Capital Outlay as a proportion of Net Fiscal Deficit (CO/NFD). (B) Own Revenue Effort Index (OREI) is consist of (i) Own Tax Collection as Proportion of Revenue Expenditure (OT/REX) and (ii) Own Non-Tax Collection as a Proportion of Revenue Expenditure (ONT/REX) and (C) Expenditure and Debt Servicing Index is consist of (i) Non-Developmental Revenue Expenditure as a proportion of Revenue Receipts
(NDRE/RR), (ii) Interest Payment as a proportion of Revenue Expenditure (IP/REX) and (iii) Debt Repayment as a proportion of Central Fiscal Transfers received by the state (DR/GCFT).

To develop the composite index we followed the methodology developed by Bhide and Panda (2002) to construct Physical Quality of Life Index (PQLI). In the construction process first of all above mentioned eight key fiscal ratios are calculated. Secondly, each ratio has been calculated for each year i.e., for 2006-07 to 2015-16 and converted indices following the methodology of Morris and McAlpin (1982). The worst and best values of each indicator were identified. For each indicator the performance of the state in each year was put on a 0 to 1 scale where, 0 represents an absolutely defined worst performance and 1 represents an absolutely defined best performance. Thus, the formula to calculate Index is as follows:

\section{Indicator Index = (Actual Value - Minimum Value $) /$ (Maximum Value - Minimum Value)}

In the third steps, the individual indicator indexes have been calculated taking simple average of number of ratios under each head of index. The justification for using a multiple indicator model to evaluate the fiscal performance is because the selection of only one indicator for measuring fiscal discipline is unjustified. For example Fiscal/ Gross Domestic Product or Revenue deficit/ revenue Receipts, this amounts to neglecting the other important fiscal variables. It also ignores the qualitative aspects of fiscal parameters like how the government spends, on what it spends, what is the proposition of debt, interest payments and their impact, how fiscal deficit is financed etc (Dholakia and Solanki, 2001). In addition to this it increases the probability of error measurement (Dholakia, 2005). This is an easy method to find out the performance of the state, as an increase in the value of an indicator index would necessarily mean improvement in the fiscal performance and vice versa.

Once the indicator index is formed, at last the composite index of fiscal performance is calculated as a simple average of the indicator indices.

Composite Index $=\Sigma$ Individual Indicator Index of each yearl Number of Individual Indicators 
According to the value of composite index the years are ranked as the year with highest index value is 1 and the year with lowest value is 0 .

\section{Model specification for Determinants of Fiscal performance}

\section{Linear regression framework}

A possible starting point for our linear panel model would follow Monfort and Mulder (2000) and Mora (2006), generalizing a cross section specification to panel data,

$$
F P_{i t}=\beta X_{i t}+\gamma Z_{i}+\alpha_{i}+\mu_{i t}
$$

Where we have: FP quantitative variable obtained by a linear or by a non-linear transformation; $X_{i t}$ is a vector containing time varying variables that includes the time-varying explanatory variables described above and $Z_{i}$ is a vector of time invariant variables that include regional dummies. In (1) the index $i(i=1, \ldots, \mathrm{N})$ denotes the states, the index $t$ $(t=1, \ldots, \mathrm{T})$ indicates the period and stands for the individual effects for each state $i$ (that can either be modelled as a error term or as $\mathrm{N}$ dummies to be estimated). Additionally, it is assumed that the disturbances are independent across states and across time.

The variables used in this study reflect the fiscal and economic structure of north eastern states along with political system. Therefore we made an attempt to examine the impoact of all these three dimensions on the level of fiscal performance in North east states. The variables identified for this study are capital expenditure (capexp), Own revenue capacity (ownrev), Net State Domestic Product (NSDP), Federal grants (grants), law and order (lawnorder) measured by dummy in which 0 is given to financial year with less than 40 civilian killings and 1 for the financial year with more than 40 civilian killings and at last political party (party) measured by dummy where 0 for congress government and 1 for non congress government.

\section{Econometric specification}

To address the stationarity properties of the timeseries, panel data unit root-tests are performed to determine whether or not the observed state- specific time series for the variables exhibits to chastictrends. Next, co-integration analysis is performed to examine whether the variables are cointegrated (i.e. whether there are stable long-term equilibrium relationships among them)in order to avoid spurious regressions. A Pedroni panel cointegration test (Pedroni 1999, 2001) has been used to estimate the co-integration between the variables.

In this paper, we made an attempt to employ following three separate methods: Pooled Least Squares (Common Constant Method), Fixed Effect and Random Effect Model to test the determinants of level of fiscal performance in North eastern states of India on panel data set for the period 2000-01 to 2015-16. Under standard conditions all estimators are consistent and the ranking of the three methods in terms of efficiency is clear: a random effects approach is preferable to the fixed effects, which is preferable to pooled OLS. What we mean by standard conditions is whether or not the state specific error is uncorrelated with the regressors $\mathrm{E}\left(\alpha_{i} \mid X_{i t^{\prime}} Z_{i}\right)=0$. If this is the case one should opt for the random effects estimation, while if this condition does not hold, both the pooled OLS and the random effects estimation give inconsistent estimates and fixed effects estimation is preferable (Asteriou and Stephen, 2007). In order to know which model is consistent and robust, Hausman test has been employed.

The theoretical inclusion of all variables that are defined above may help out to make the econometric models running under pooled, fixed and random effect specification. In the fixed effects method the constant is treated as group specific. This means that the model allows for different constants for each state. The fixed effects estimator is also known as the least-squares dummy variables (LSDV) estimator because in order to allow for different constants for each state, it includes a dummy variable for each state. To incorporate state specific effects, a fixed effects model could take a form:

$$
\begin{array}{r}
\operatorname{Ln}(F P)_{i t}=\alpha_{i t}+\beta_{1} \operatorname{Ln}(\text { capexp })_{i t}+\beta_{2} \operatorname{Ln}(\text { ownrev })_{i t}+\beta_{3} \\
\operatorname{Ln}\left(\text { grants }_{i t}+\beta_{4} \text { lawnorder }_{i t}+\beta_{5} \text { polfreg }_{i t}+\beta_{6}\right. \\
\text { party }_{i t}+\mu_{i t}
\end{array}
$$

Where:

$\alpha_{i t}$ is a state effects that also depends on time. $\beta_{1^{\prime}}$ $\beta_{2^{\prime}} \beta_{3^{\prime}} \beta_{4^{\prime}} \beta_{5^{\prime}} \beta_{6}$ are the coefficients of respective variable. 
An alternative method of estimation is the random effects model. The difference between the fixed effects and the random effects method is that the latter handles the constants for each section not as fixed but as random parameters. The random effects model has two advantages: it has fewer parameters to estimate compared to the fixed effects method and allows for additional explanatory variables that have equal value for all observations within a group (i.e., it allows using dummies). To incorporate all the states and time effects, random effect model take the form:

$$
\begin{aligned}
& \operatorname{Ln}(F P)_{i t}=\alpha_{0}+\alpha_{i}+\delta_{t}+\beta_{7} \operatorname{Ln}(\text { capexp })_{i t}+\beta_{8} \\
& \text { Ln(ownrev) }{ }_{i t}+\beta_{9} \text { Ln(grants) }{ }_{i t}+\beta_{10} \text { lawnorder }_{i t} \\
& +\beta_{11} \text { polfreg }_{i t}+\beta_{12} \text { party }_{i t}+\mu_{i t}
\end{aligned}
$$

Where:

$\alpha_{0}$ is intercept, $\alpha_{i}$ is a state effects and $\delta_{t}$ is time effect. $\beta_{7^{\prime}} \beta_{8^{\prime}} \beta_{9^{\prime}} \beta_{10^{\prime}} \beta_{11^{\prime}}, \beta_{12}$ are the coefficients of respective variable.

\section{Hausman Test for Model Specification (Fixed Effects vs. Random Effects)}

The Hausman test is formulated to assist the choice between the fixed effects and random effects approaches. For the panel data, the appropriate choice between the fixed effects and the random effects methods examine whether the regressors correlate with the individual effect. The advantage of the use of the fixed effects estimator is that it is consistent even when the estimators are correlated with the individual effects. The Hausman test uses the following test statistic:

$$
H=\left(\beta^{F E}-\beta^{R E}\right)\left[\operatorname{Var}\left(\beta^{F E}\right)-\operatorname{Var}\left(\beta^{R E}\right)\right]^{-1}\left(\beta^{F E}-\beta^{R E}\right)
$$

If the value of the statistic is small and the difference between the estimates is insignificant. So, we reject the null hypothesis that the random effects model is consistent and we use the fixed effects estimators. In contrast, large value of the Hausman statistics implies that the random effects are more appropriate.

\section{RESULT AND DISCUSSION}

\section{Fiscal performance of states based on indicators}

The individual indices of fiscal performance of NE provide interesting results to have a cumulative assessment of constraints present in fiscal structure in NE states. The deficit burden of the NE states is penetrated deep and might be due to different other types of non plan revenue expenditure other than the interest payment. Though the NE states are special category states and are getting more as grant than the loan from the central government still these states are unable to attain revenue sufficiency and going for debt. The average of debt as a percentage of GSDP shows an increasing trend for the NE states which is negative from the view of point of revenue management and planning for developmental expenditure. However, in terms of composite fiscal index the states have varied considerably. Table 1 shows the results of composite fiscal performance

\begin{tabular}{|c|c|c|c|c|c|c|c|c|}
\hline 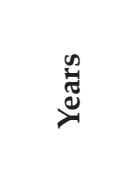 & 䒿 & 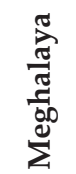 & 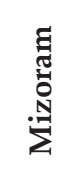 & 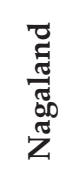 & 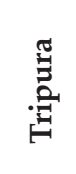 & 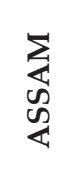 & 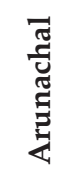 & 韋 \\
\hline 2006-07 & 0.36 & 0.70 & 0.53 & 0.41 & 0.51 & 0.69 & 0.35 & 0.80 \\
\hline 2007-08 & 0.29 & 0.39 & 0.48 & 0.51 & 0.50 & 0.57 & 0.22 & 0.77 \\
\hline 2008-09 & 0.36 & 0.35 & 0.41 & 0.49 & 0.39 & 0.59 & 0.28 & 0.54 \\
\hline 2009-10 & 0.43 & 0.33 & 0.37 & 0.37 & 0.35 & 0.40 & 0.42 & 0.41 \\
\hline 2010-11 & 0.36 & 0.25 & 0.49 & 0.37 & 0.33 & 0.35 & 0.33 & 0.44 \\
\hline 2011-12 & 0.31 & 0.31 & 0.58 & 0.29 & 0.42 & 0.39 & 0.25 & 0.30 \\
\hline 2012-13 & 0.44 & 0.34 & 0.25 & 0.23 & 0.42 & 0.33 & 0.29 & 0.45 \\
\hline 2013-14 & 0.28 & 0.43 & 0.34 & 0.32 & 0.44 & 0.24 & 0.35 & 0.41 \\
\hline 2014-15 & 0.35 & 0.53 & 0.22 & 0.31 & 0.41 & 0.29 & 0.31 & 0.47 \\
\hline 2015-16 & 0.34 & 0.47 & 0.32 & 0.60 & 0.49 & 0.41 & 0.42 & 0.31 \\
\hline
\end{tabular}
index of NE states.

Table 1: Composite fiscal performance index of North eastern States of India

Sources: calculated by Author.

The composite fiscal performance of north eastern states shows a steady decline in fiscal performances. The fiscal performance of most of the NE states is inconsistent and deteriorating over the years. The states such as Manipur, Sikkim, Mizoram, Arunachal and Meghalaya are worst performing states in terms of fiscal setup. While as, the states such as Nagaland, Tripura and Assam have improving fiscal performance over last few years. The plausible explanation of this fiscal performance of Ne states might be due to the increasing deficit burden, poor own revenue capacity and high expenditure-debt serving ratio. 


\section{Determinants of Fiscal performance in NE of India}

To ascertain the stationarity of the variables, panel unit root tests are employed as presented in Table 4. Based on the Panel ADF unit root test, the null hypothesis of the presence of unit root is accepted for all the variables under examination. That is, all other variables such as fiscal performance, own revenue, capital expenditure, NSDP and grants are non stationary at level. After converting the series at first difference the variables under examination become stationary. Therefore the variables are integrated of order I(1) instead of order zero, I(0).

Table 2: Estimated results of Penal Augmented DickeyFuller unit root test

\begin{tabular}{cccccc}
\hline Variables & \multicolumn{2}{c}{ At level } & \multicolumn{2}{c}{ Difference } & \\
\cline { 2 - 6 } & $\begin{array}{c}\mathbf{t}- \\
\text { statistic }\end{array}$ & P value* $^{\mathbf{t}-}$ & $\begin{array}{c}\mathbf{P} \\
\text { statistic }\end{array}$ & Order \\
value* & \\
\hline $\begin{array}{c}\text { Own } \\
\text { revenue }\end{array}$ & 7.70895 & 1.0000 & -1.90460 & 0.0284 & $\mathrm{I}(1)$ \\
NSDP & -0.219 & 0.9521 & -6.413 & 0.0000 & $\mathrm{I}(1)$ \\
$\begin{array}{c}\text { Capital } \\
\text { Exp. }\end{array}$ & 1.66552 & 0.059 & -6.59686 & 0.0003 & $\mathrm{I}(1)$ \\
$\begin{array}{c}\text { Grants } \\
\text { FP }\end{array}$ & -0.49792 & 0.9998 & -3.54674 & 0.0002 & $\mathrm{I}(1)$ \\
\hline
\end{tabular}

Sources: Calculated by Author; M Mackinnon (1991)* 1\% level of significance ** $5 \%$ level of significance.

After performing unit root test and concluding that variable are integrated of order I(1), a co-integration test is performed to determine whether the variables have a long-run relationship. The co-integration test for the Fiscal performance model is based on the Pedroni panel co-integration tests Pedroni $(1999,2001)$. Unlike other panel co-integration tests such as Johansen $(1988,1995)$, Pedroni panel cointegration test is able to examine the properties of spurious regressions and residual-based tests for the null hypothesis of no cointegration for both homogeneous and heterogeneous panels. Further, the panel co-integration test fulfills the conditions under which tests for the null hypothesis of no cointegration with homogeneous slope coefficients are asymptotically equivalent to raw panel unit root tests. The results of the panel co-integration test are shown in table 3 .

\section{Co-integration}

Table 3: Pedroni Residual Cointegration Test

\begin{tabular}{|c|c|c|c|c|}
\hline \multirow{2}{*}{\multicolumn{5}{|c|}{$\begin{array}{l}\text { Series: fpownrevenue grants lawnor } \\
\text { polpartycaptialexp } \\
\text { Sample: } 20012016\end{array}$}} \\
\hline & & & & \\
\hline \multicolumn{5}{|c|}{ Null Hypothesis: No cointegration } \\
\hline \multicolumn{5}{|c|}{$\begin{array}{l}\text { Alternative hypothesis: common AR coefs. (within- } \\
\text { dimension) }\end{array}$} \\
\hline & Statistic & Prob. & $\begin{array}{l}\text { Weighted } \\
\text { Statistic }\end{array}$ & Prob. \\
\hline $\begin{array}{l}\text { Panel } \\
\text { v-Statistic }\end{array}$ & -3.34025 & 0.9996 & -3.13307 & 0.9991 \\
\hline $\begin{array}{l}\text { Panel rho- } \\
\text { Statistic }\end{array}$ & 3.491305 & 0.9998 & 3.302758 & 0.9995 \\
\hline $\begin{array}{l}\text { Panel PP- } \\
\text { Statistic }\end{array}$ & -7.49609 & 0.0000 & -3.57 & 0.0002 \\
\hline $\begin{array}{l}\text { Panel ADF- } \\
\text { Statistic }\end{array}$ & -6.27569 & 0.0000 & -1.96862 & 0.0245 \\
\hline
\end{tabular}

Alternative hypothesis: individual AR coefs. (betweendimension)

\begin{tabular}{lll}
\hline & Statistic & Prob. \\
\hline Group rho- & & \\
Statistic & 3.802599 & 0.9999 \\
Group & & \\
P-Statistic & -6.43085 & 0.0000 \\
Group ADF- & & \\
Statistic & -4.14173 & 0.0036 \\
\hline
\end{tabular}

The estimated results reveal that all the variables of the model are jointly co-integrated and have a long-run relationship. The table further shows that among the eleven different statistics values six coefficients/statistic values are significant at $5 \%$ level of significance. Therefore it suggests that the variables under consideration are having long run association and are moving together in long run.

\section{Empirical results}

After predicting the existence of long run relationship between variable, consequently, the variables are used together in predicting the behavior of fiscal performance indicator. The model estimated for understanding the factors which determine the fiscal performance of north Eastern states of Indian are generally of two alternative estimation methods such as fixed effects and random-effects methods but being the penal data analysis we further tried to use pooled estimation model also to compare the results. The fixed-effects method is expected to 
remove the effects of any time-invariant unobserved attribute of each state, which may be correlated with one or more of the explanatory variables. In the fixed-effects model, the intercept term is eliminated during data transformation. Therefore, there is no constant term in the fixed-effects model. In the random-effects model, however, it is assumed that the unobserved attribute of each state is uncorrelated with each explanatory variable at all times. Thus, the constant term remains intact in the random-effects model. Both methods were estimated by the latest version of Eviews.

In the estimation of the fiscal performance model, the Hausman specification test (Hausman, 1978) is employed to determine whether fixed or random effect model is preferable, result shows that the random effect model is efficient and consistent, and thus it is the preferred model in the panel analysis. Consequently, the interpretation of results is based on the random effect and fixed effect models. The panel data regression result for the determinants of fiscal performance of NE states is presented in Table 6 followed by table 4 which show the result of Hausman specification test.

Table 4: Estimated results of Models

\begin{tabular}{cccc}
\hline \multicolumn{4}{c}{ Panel data estimation } \\
\hline Variables & Pooled & Fixed Effect & $\begin{array}{c}\text { Random } \\
\text { Effect }\end{array}$ \\
\hline Constant & $-1.95(0.056)^{*}$ & ---- & -1.95 \\
& & & $(0.026)^{*}$ \\
Lncapitalexp & $-0.097(0.23)$ & $0.023(0.006)^{*}$ & -0.097 \\
$(0.162)$ \\
Lnownrevenue & $0.256(0.003)^{*}$ & $0.288(0.00)^{*}$ & $0.256(0.008)^{*}$ \\
Lngrants & $0.916(0.00)^{*}$ & $0.028(0.787)$ & $0.916(0.000)^{*}$ \\
InLawnarder & $-0.352(0.044)^{*}$ & -5.160 & -0.352 \\
Polfreg & $0.037(0.656)$ & $1.205(0.501)$ & $0.037(0.602)$ \\
Polparty & $-0.01(0.93)$ & $-1.99(0.436)$ & -2.39 \\
R2 & 0.61 & 0.87 & $(0.025)^{*}$ \\
F-Statistic & $31.75(0.000)$ & $25.51(0.000)$ & $24.13(0.000)$ \\
No. of states & 8 & 8 & 8 \\
\hline
\end{tabular}

Sources: Calculated by Author; Note: Standard errors in parentheses; * and ** signify $5 \%$ and $10 \%$ significance levels, respectively.

The table 6 revel interesting results in terms of the factors which determine the status of fiscal performance of North Eastern states. In line with prior expectations, the results show that is a negative impact of capital expenditure on fiscal performance. However the impact is indifferent in all the models. Random effect model suggests negative and insignificant impact whereas fixed effect model shows positive and significant impact. However the impact in all the models is of little or no significance across all the models. The low coefficient of about -0.09 implies that the effect of capital expenditure on fiscal performance is relatively negligible and week. This is the reflection of the inefficient capital formation structure of NE states. The plausible explanation of this insignificant and week relationship could be the poor industrial and services sector in NE states where each unit of capital spending does not provide efficient dividend and the amount spend for capital formation always went in losses. The results are inconsistent with Nayak and Rath, (2010).

The estimated impact of own revenue on fiscal performance is statistically significant and positive in all the models; this corroborates the findings of Kaur et al. (2014). The results suggest that the relatively higher share of own revenue to total revenue of the states, is conducive for the better fiscal performance of NE states. The results were expected due to the fact that all most all the NE states felt crunch of funds to carry spending activities efficiently and are heavily dependent on central funds and on high interest loans which creates extra pleasure on fiscal performance. Therefore in such situation increase in own revenue increases the economic as well as revenue base of the NE states and thus leads to efficient fiscal performance.

Similarly, the results further show that there is positive and significant impact of grants on improving the fiscal performance. The results are significant according to pooled and random effect model which implies that this impact is statistically significant across the states. The results suggest that 1 percent increase in grants improve fiscal performance by almost 1 percent (0.96) which shows a greater level of elasticity of fiscal performance. The results were expected due to the fact that all the North Eastern states face revenue crunch and they are always in way of augmenting new ways to get revenue for carrying out expenditure practices. In such situation increase in grants, which are non 
repayable, improve the revenue base and results stability in fiscal structure.

Further, the impact of law and order, which is measured by number of civilian killings, on fiscal performance is mixed but significant in all the models. The magnitude of impact varies across the models but results are significant at $5 \%$ and $10 \%$ level of significance. The fixed effect model shows 1 percent increase in law and order situation (one percent increase in civilian killings) lead to decrease fiscal performance by 5.1 percent whereas random effect shows a decline of 0.36 percent. Though both models provide different magnitude of relationship but both models shows a negative relationship of law and order on fiscal performance. It might be due to the fact that north eastern states are considered as conflict states where insurgency and civil conflicts are often seen. Therefore even increase in civilian killings disturb the economic activities on one hand and on other hand pushes government expenditure on law and order and security to new highest and thus results imbalance in fiscal performances. Also with increasing civilian killings governments are forced to compensate and provide ex-gratia to the families which further increase non developmental expenditure and thus deteriorate fiscal performance.

The estimated results show that political fragmentation has insignificant but positive impact on fiscal performance of North Eastern States. This indicates the coalition or multi-party system of government is suitable for North Eastern states to manage the fiscal system efficiently due to the fact that all the north eastern states are tribal states in which each state has number of tribes which need proper representation in government to represent their respective tribe. However the insignificant impact could be adduced to the common practice among the north eastern states of forming parties not on the bases of tribe but affiliating to national party or any other regional party.

Lastly, political party has a negative significant impact on level of fiscal performance. The results support the findings of Dholakia et al. (2004) and oppose the finding of Elena and Nagarajan, (2007). The result implies that change from congress ruling regime to non congress government the level of fiscal performance reduces. The results are indifferent in both the models. The fixed effect model shows negative but insignificant impact whereas random effect shows negative and significant impact. According to random effect model change in ruling government from congress to non congress the fiscal performance reduces by 2.3 percent. The plausible reason could be the congress ruling in center over the years which in one way or other way favor the regional congress government in terms of grants and different types of allocations and projects which help state government to stabilize fiscal performance.

Table 5: Correlated Random effects; Hausman Test

\begin{tabular}{|c|c|c|c|c|}
\hline \multicolumn{5}{|c|}{ Null Hypothesis: Fixed vs random effects } \\
\hline \multicolumn{2}{|c|}{ Test Summary } & $\begin{array}{l}\text { Chi-Sq. } \\
\text { Statistic }\end{array}$ & $\begin{array}{c}\text { Chi-Sq. } \\
\text { d.f. }\end{array}$ & Prob. \\
\hline \multicolumn{2}{|c|}{ Cross-section random } & 11.688142 & 6 & 0.725 \\
\hline \multicolumn{5}{|c|}{ Cross-section random effects test comparisons: } \\
\hline Variable & Fixed & Random & $\operatorname{Var}($ Diff.) & Prob. \\
\hline lncapitalexp & 0.023595 & -0.097912 & 0.001087 & 0 \\
\hline lnownrevenue & 0.28831 & 0.256224 & 0.006987 & 0.1087 \\
\hline Ingrants & 0.028413 & 0.916276 & 0.017436 & 0 \\
\hline lawnorder2 & -5.16076 & -0.352707 & 0.016931 & 0.039 \\
\hline polfreg & 1.2058172 & 0.037919 & 0.011151 & 0.2548 \\
\hline polparty & -1.995264 & -2.392702 & 0.016079 & 0.1289 \\
\hline
\end{tabular}

Sources: Calculated by Author.

To check the most appropriate model between fixed effects model and random effects we use Hausman specification test which compares the fixed versus random effects under the null hypothesis that the individual effects are not correlated with the other explanatory variables in the model (Hausman, 1978). If correlated (H0 is rejected), a random effect model produces biased estimators, violating one of the Gauss-Markov assumptions (Park, 2009). According to the Hausman specification test we cannot reject the null hypothesis as probability value is greater than $5 \%$ level of significance. This implies that random effect model is more appropriate and preferred one.

\section{CONCLUSION}

Given the persistent and deteriorating fiscal performance of North Eastern States despite moderate economic growth in recent years, this study examined the status and determinants of fiscal performance of North eastern states of India using different panel data estimation technique. Fiscal performance was measured by composite 
index of different indices and Pedroni panel cointegration test was employed to establish the long run relationship between the variables. Empirical analysis revealed that the north eastern states are poor performing states in terms of fiscal indicators. In between the north eastern states the level of fiscal performance based on different indicators such as revenue, debt, and capital formation is not only poor but deteriorating over the years.

Further, in analyzing the factors which determine the level of fiscal performance the empirical analysis showed that own revenue capacity, federal grants, law and order situation and political party governing in state are the significant factors which determine the level of fiscal performance in North Eastern state's of India.

Therefore, the peculiar situation in the North Eastern states and the inherent restrictions implies that these states are faced with hurdles in the implementation of policies. NE states are favored states, getting large tax preferences, exempted from paying direct taxes; enjoy a number of subsidies, have rigid/undefined property rights regime, which hinders the identification of the potential of the economy. We believe that it is not protectionist policies rather it is the failure to harmonize protectionism with policies geared towards efficient resources management policies that undermines the fiscal health of the states, resulting in depressed developmental outcomes. Therefore, the institutional arrangement which vitiates fiscal health of the North Eastern states and adversely affects economic development is the outcome of the incongruity between protectionism and policies aimed at resources utilization. Therefore, we term such imbalance as "Fiscal tribal dilemma" or "Fiscal Regional Dilemma".

\section{REFERENCES}

Acaharya, S. 2002. Macroeconomic Management in the 1990. Economic and Political Weekly, 37(16): 1515-38.

Ahluwalia, M.S. 2002. India's Vulnerability to External Crisis: An Assessment. In: M. S Ahluwalia, S.S. Tarapore and Y.V.Reddy (eds.) Macroeconomics and Monetary Policy: Issues for Reforming Economy. Essays in Honor of C. Rangarajan, Oxford University Press.

Bhide, S. and Panda, M. 2002. Evaluating Quality of Budgets with a Composite Index. Economic and Political Weekly, 30: 1117-11180.
Buiter, W.H. and Patel, U.R. 1992. Debt, Deficit and Inflation: An Application to the Public Finance of India. Journal of Public Economics, 47: 172-05.

Dash, A.K. 2015. Growth and Public Debt Scenario of North Eastern States of India. International Journal of Management and Social Science Research Review, 1(12): 142-149.

Dash, A.K. and Tiwari A. 2011. Is Inequality in Fiscal Performance Nonlinear Stationary in Northeastern States of India? International Journal of Development Research and Quantitative Techniques, 1(2): 56-62.

Dash, A.K. 2011. Fiscal Performance of Special Category States in India: A Case Study of Tripura State Finance. Euro Economica, 29(3): 121-132.

Dholakia, R.H., Rammohan T.T. and Karan, N. 2004. Fiscal Sustainability of Debt of States. Report Submitted to $12^{\text {th }}$ Finance Commission of India, IIM, Ahmadabad.

Dholakia, A. and Solanki, T. 2001. Ranking States on Fiscal Performance, paper presented at seminar on Economic Reforms, Gujarat University, Ahmadabad.

Elena, I.L.L. and Nagarajan, M. 2007. Sub national Fiscal Sustainability Analysis: What Can We Learn from Tamil Nadu?. Economic and Political Weekly, 29(42): 52-67.

Hassan, S. and Mishra, B. 2017. Does infrastructure matters in government spending? A case study of Jammu and Kashmir (India) with co-integration approach. Journal of Infrastructural Development, 9(2): 1-16.

Hassan, S.U., Mishra, B. and Suresh, P.S. (2016a). A MultiDimensional Approach to the Determinants of Tax revenue: The case of the state of Jammu and Kashmir (India). Journal of Finance and Risk Management, 7(3): 66 -104 .

Hassan, S.U., Mishra, B. and Suresh, P.S. 2016b. An Analysis of Productivity and Efficiency of Tax system in the state of Jammu and Kashmir. International Journal of Business and Economic review, 4(1): 208-226.

Hassan, S.U. and Mishra 2017. Government expenditure and Economic growth in the state of Jammu and Kashmir: A unit root and Co-Integration Approach with Error Correction Model. International Journal of Statistics and Economics, 18(2): 58-86.

Hausman, J.A. 1978. Specification Tests in Econometrics. Econometrica, 46(6): 1251-71.

https://www.rbi.org.in/scripts/PublicationsView. aspx?id=15767

Kaur, B., Mukherjee, A., Kumar, N. and Ekka, A.P. 2014. RBI Working Paper Series No. 07, Debt Sustainability at the State Level in India.

Lahiri, A.K. and Kannan, R. 2001. India Fiscal Deficits and their Sustainability in perspective. Paper Presented at the World Bank-NIPFP Seminar on Fiscal Policies for Growth.

Mishra, B. 2006. Fiscal Policy In North East India. New Delhi: Akansha Publishing House.

Mishra, B., Suraesh, P.S. and Ovung, K.Z. 2005. Political economy of Public Expenditure Growth In North Eastern 
States of India: A case study of Nagaland. Asian- Afarican Journal of Economics, 5(1): 17-33.

Monfort, B. and Mulder, C. 2000. Using credit ratings for capital requirements on lending to emerging market economies - possible impact of a new Basel accord. IMF Working Papers 00/69.

Nayak, S.K. and Rath, S.S. 2010. A Study on Debt Problem of Special Category States (Revised). Study Conducted for the $13^{\text {th }}$ Finance Commission, Government of India.

Patnaik, R.K. 1996. Budget Deficit in India: Measurement, Analysis and Management. Ph.D Thesis submitted to IIT of Delhi.

Pedroni, P. 1999. Critical Values for Co-integration Tests in Heterogeneous Panels with Multiple Regressors. Oxford Bulletin of Economics and Statistics, 61(S1): 653-70.

Pedroni, P. 2000. Fully Modified OLS for Heterogeneous Cointegration Panel in Nonstationary Panels, Panel Cointegration and Dynamic Panels. Advances in Econometrics, 15: 93-130.
Rajaraman, I., Bhide, S. and Patnaik, R.K. 2005. A Study on Debt Sustainability at State Level in India. Reserve Bank of India, Mumbai.

Sarma, A. and Nayak, S. 2006. Growth and Equity in the PostReform Period: Experience of the North Eastern States. Paper presented in the Silver Jubilee Conference of CESS, Hydrabad. January $7^{\text {th }}-8^{\text {th }}$.

Suresh, P.S. and Mishra, B. 2010. Public Expenditure and Human Development in North-East India: A Case Study of Meghalaya. In P. Nayak (Ed.), Growth and Human Development in North-East India, New Delhi: Oxford University Press, pp. 233-243.

Ucar, N. and Omay, T. 2009. Testing for Unit Root in Nonlinear Heterogeneous Panels. Economics Letters, 104(1): 5-8. 